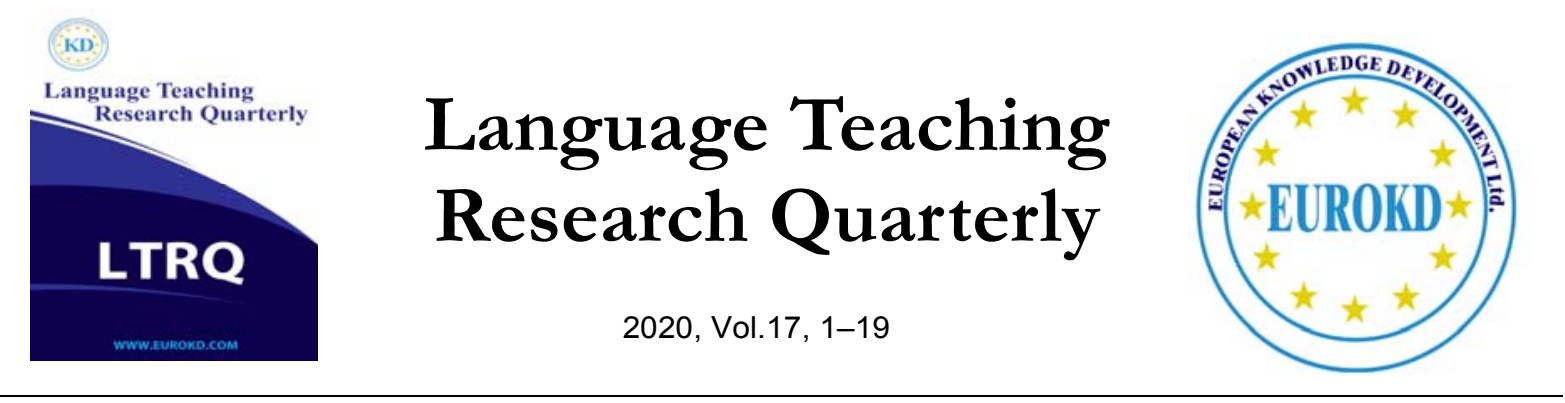

\title{
Promoting Intercultural Communicative Competence through CLIL in Greek Primary Education
}

\author{
Fotini Lagou, Vasilios Zorbas* \\ Hellenic Open University, Greece
}

Special Issue: Interculturalism in Second Language Teaching

Received 26 November 2019 Accepted 29 March 2020

\begin{abstract}
Intercultural Communicative Competence constitutes one of the most burning issues in foreign Language education given the challenges cultural diversity poses to our formerly homogeneous classrooms. This article attempts to explore the intercultural practices of EFL teachers working in primary schools in Greece, as well as the extent to which Content and Language Integrated Learning (CLIL), which is still striving for recognition in the particular context, promotes the development of intercultural knowledge, attitudes and skills. Using the mixed method research model, the present study investigates the importance primary EFL teachers in Greece ascribe to intercultural objectives, the way the cultural dimension is articulated in professional praxis, the potential of a CLIL approach to foster intercultural sensitivity, as well as the perceived gains and challenges CLIL practitioners face in primary education. The analysis of the findings shed light on a number of constraining factors along with the potential of CLIL to circumvent obstacles and promote intercultural dialogue. It is hoped that the implications of the findings will pave the way for future full-scale research that will serve as a basis for the much-needed change in intercultural education and policy in Greece.
\end{abstract}

Keywords: Content and Language Integrated Learning, Intercultural Communicative Competence, Intercultural Education, Teacher Training 


\section{Introduction}

In an era of globalization, a profound transformation has swept through the Greek society affecting the dynamics of its teaching contexts. Greece has been experiencing an unprecedented rise in the number of immigrants, turning formerly homogeneous classrooms into a multicultural mosaic. This research stems from the need to respond to this challenge of cultural diversity in Greek primary education settings. By adopting a pluralist perspective, this article seeks to provide a theoretical and conceptual framework as well as meaningful insights into key stakeholders in the educational arena regarding intercultural teaching through the Content and Language Integrated Learning model (CLIL). The research is predicated on the belief that the role of educators is to contribute to change rather than interpret and perpetuate the maladies of our societies (Coyle, 2000). We hope this study will contribute to the transformation of Greek EFL teachers from "impresario[s] of a certain linguistic performance, [to] catalyst[s] of an everwidening critical [inter]cultural competence” (Kramsch, 1995, p. 8).

\section{Literature review}

The idea of promoting cultural learning and understanding in the field of foreign language teaching and learning (FLTL) is by no means a new concept in the relevant literature along with the general consensus on the immanent cause-and-effect relationship between language and culture (Ho, 2009; Kramsch, 1998a; Liddicoat, Papademetre, Scarino and Kohler, 2003; Risager, 2005). As Mitchell and Myles (2004, p. 235) point out, "language and culture are not separate, but are acquired together, with each providing support for the development of the other." In the same vein, compounds such as linguaculture (Friedrich, 1989), languaculture (Agar, 1994), language in culture (Crozet \& Liddicoat, 2000), language-and-culture (Liddicoat et al., 2003), and culture language (Papademetre \& Scarino, 2006) mirror the interdependence of the two constructs.

For foreign language (FL) educators, the implications of language and culture being intricately interwoven have been far reaching in that teaching a FL does not simply involve developing linguistic knowledge and skills but also "the ability to use the language in socially and culturally appropriate ways" (Byram, Gribkova, \& Starkey, 2002, p. 4), while language teachers are simultaneously teachers of culture given that language is not culture proof (Byram, 1989; Cakir, 2006; Sudhoff, 2010). Language, therefore, is not learned in a vacuum and "the person who learns a language without learning culture risks becoming a fluent fool" (Bennett, Bennett and Allen, 2003, p. 237).

However, notions of cultural literacy have been strongly influenced by the dominance of native-speaker norms and the cultural dimension of FLTL has been monolithically confined to the 'target' Anglo-American cultures, failing to embrace a more inclusive scope of cultural awareness. Bearing this in mind, Woodman's (2009, cited in Race, 2011, p. 9) caustic comment challenges the reductionist cultural educational paradigm in a shrinking multicultural world:

Being British is about driving in a German car to an Irish pub for a Belgian beer, then travelling home, grabbing an Indian curry or a Turkish Kebab on the way, to sit on Swedish furniture and 
watch American shows on a Japanese TV - And the most British thing of all - suspicion of anything foreign.

The prestigious, prioritized status of British and American cultures has generated a lot of discussion on the type of culture educators should promote. Holliday (2004) positions the cultural dimension along essentialism - non-essentialism continuum and embraces a nonessentialist view, adopting an ethnorelative rather than an ethnocentric cultural stance. Adding to the discussion, Aoki and Smith (1999, cited in Reimann, 2010) stress the need for a negotiated cultural agenda in order to avoid marginalization and stereotyping. Similarly, Byram et al. (2002) warn against cultural ethnocentrism, for the pigeonholing of cultures may lead to preconceived ideas and cultural ignorance. The culture-biased emphasis on the target cultures of the inner circle (Kachru, 1985), along with the corrosive effects on the cultural make-up of cultural minorities, has also been criticized by researchers in the Greek context (Papalexatou \& Zorbas, 2019a (in press); Papalexatou \& Zorbas, 2019b (in press); Zorbas and Karras, 2019; Karakatsanis, Spinthourakis, Zorbas (2018); Papakyritsopoulou \& Zorbas, 2017; Griva \& Zorbas, 2017; Papalexatou \& Zorbas, 2017; Zorbas \& Papalexatou, 2016; Papalexatou \& Zorbas, 2015; Sifakis \& Sougari, 2003) who point to the fact that in today's classrooms students welcome more global approaches. Admittedly, culture-exclusive practices do not pave the way toward meaningful interactions between Native Speakers (NSS) and Non-Native speakers (NNS), or between NNS and NNS of different backgrounds, which constitute the norm of many in the expanding circle. Concluding, Banks and Banks (2007, cited in Race, 2011, p. 8) highlight the importance of revisiting culture teaching in a changing world:

We are living in a dangerous, confused, and troubled world that demands leaders, educators, and [needs] classroom teachers who can bridge impermeable cultural, ethnic, and religious borders, envision new possibilities, invent novel paradigms, and engage in personal transformations and visionary action.

In the light of the above, there is no doubt that English Foreign Language (EFL) educators should cease to function as a censor, favoring from a plethora of cultural ideas those that seem acceptable (Mathews, 2000). Failing to adopt a more global perspective of cultural integration will not help meet some of the challenges we are currently facing (namely, fanaticism, chauvinism, racism, religious fundamentalism and xenophobia) (Race, 2018; Rashid \& Tikly, 2010).

Having established the need for a global eye on cultural integration, questions arise as to the cultural content teachers bring to EFL teaching. Given the ambiguous, imperceptible nature of culture, depicted in the plethora of definitions of the term, deciding on the cultural content is no easy feat. Historically, although the study of a FL has long been associated with understanding an additional culture, there has been a constant reassessment as to what should be taught (Liddicoat \& Scarino, 2013), which Lo Bianco and Crozet (2003) refer to as the problem of representation. In general, the concept of culture has deviated over time from the traditional paradigm in which cultural teaching was limited to the high or highbrow (Kramsch, 1995) culture of particular societies, and low culture elements or what Lawes $(2007$, p. 87, cited in 
Diamantidaki \& Carruthers, 2018, p. 79) terms ethno-culture have been added to the curricular agenda (Crozet \& Liddicoat, 2000). However, it would be a fallacy to restrict cultural awareness to topics such as food, festivals, traditions and dress code (Quist, 2013). Focusing on the elements of culture, which are above sea level according to Hall's (1976, cited in McDougald, 2013) Cultural Iceberg Model, we tend to explore only the tangible part of culture and omit the unconscious part related to values, beliefs, rules of etiquette, gender roles etc. Moreover, culture is too complex to be reduced to mere facts and stereotypical representations. Morgan and Cain (2000) challenge the unidirectional presentation of facts in cultural studies and support a more relativized understanding of other cultures. Similarly, Tomlinson (2001, p. 5, cited in Saniei, 2012) contends that cultural information provided as a fixed body of information may contribute to useful cultural knowledge but fails to promote cultural awareness which involves "a gradually developing inner sense of the equality of cultures, an increased understanding of your own and other people's cultures, and positive interest in how cultures both connect and differ" (p. 12). In essence, challenging the knowledge-based model of culture teaching entails the shift from a cultural pedagogy to an intercultural one, which decenters learners from preconceived assumptions and contributes to the transformation of their identity and worldview (Liddicoat \& Scarino, 2013).

A wide spectrum of terms, which abound in the relevant literature (e.g., biculturalism, multiculturalism, communicative competence, cross-cultural adaptation, cross-cultural awareness, global competence, international competence, international communication, intercultural interaction, metaphoric competence, transcultural communication etc.) bring to the fore the fact that intercultural education has received considerable attention (Fantini, 2009, p. 196). However, when the question arises as to the best approach to intercultural teaching, research has been inconclusive (Koro, 2016). At this point, it should be stressed that in seeking the best approach or method, we do not pursue a prescriptive "statement of orthodox practice but rather explore the best possible [practice]" (Liddicoat \& Scarino, 2013, p. 3).

Among various models proposed for the development of intercultural competence, integrated ones are gaining momentum, with CLIL attracting sustained attentiveness. Even though CLIL programs [from total immersion to language showers (Papadopoulos \& Griva, 2014; Smit \& Dalton-Puffer, 2007)] have become institutionalized practice in several European countries for their perceived benefits (Griva, Chostelidou, \& Panteli, 2014), yet it remains a rather nascent approach in Greece (Oikonomou, 2013). Accordingly, a research carried out in the Greek context, has shown that the vast majority of FL teachers $(63 \%)$ are not familiar with CLIL, while a big percentage (81.4\%) state that CLIL constitutes an unrealistic aspiration for lower level students (Griva et al., 2014). Nonetheless, an interest in early language learning has spurred a 'the earlier the better' movement, rallying for CLIL introduction even at pre-school stages (Coyle, Hood, \& Marsh, 2010; Manjarrés, 2009). From another perspective, Crozet and Liddicoat $(2000$, p. 2) add that "the recognition that culture pervades all aspects of language use has meant that the teaching of culture can no longer be delayed to advanced levels of language learning". 
Still, relative studies focus mostly on secondary education "because of the assumption that the attainment of intercultural competence presumes a cognitive ability and morality that many young children have yet to acquire" (Takeuchi, 2015, p. 47). The current study aims to address this gap in practice-informed literature in the Greek context by positing that intercultural sensitivity is a lifelong process which has a place in the early stages of primary education, where stereotyping and prejudice are not deeply ingrained.

\section{Methodology}

\section{Aim and research questions}

As already stated, the overarching goal of the present study was to investigate the attitudes of Greek EFL primary teachers regarding the place of intercultural teaching and learning in existing practices and the potential CLIL has in its different manifestations of implementation to promote ICC. In line with recent research, this study was grounded in the assumption that intercultural sensitivity is a lifelong process which has a place in the early stages of primary education, where stereotyping and prejudice are not deeply ingrained.

More particularly, the following four research questions were addressed:

- How much importance do primary EFL teachers in Greece attribute to the development of Intercultural Communicative Competence (ICC)?

- To what extent is the cultural dimension incorporated in their practices?

- To what extent is CLIL adopted as a method for developing intercultural sensitivity?

- What are the perceived benefits and/or constraints of the CLIL approach?

\section{Research instruments: rationale, design and procedures}

Acknowledging that this research was too complex to adopt a purist approach, the current study is grounded in the mixed methods research model. On a more practical note, the study used varied techniques, namely a questionnaire, semi-structured interviews as well as lesson observation, which allowed a robust analysis of the findings. In doing so, it adopted a research approach referred to as methodological triangulation, which seeks pluralism rather than convergence.

\section{The questionnaire}

A web-based questionnaire was the initial instrument selected to collect data on the key issues, which emerged, from day one of the study. It addressed EFL primary school teachers in Greece of both the state and private sector (including experimental schools) and was divided into four sections. The first section sought to collect some personal information about the respondents' gender, age group, their teaching experience and qualifications as well as some background data exploring their intercultural profile and degree of familiarization with CLIL. Section two aimed to determine the respondents' predispositions toward intercultural education. Bearing in mind the affective, behavioral and cognitive dimension of ICC, this part included closed-ended Likert scale items in which the respondents had to rank their responses from 'not important' to 'very 
important' or from 'strongly disagree' to 'strongly agree'. The next two parts of the survey addressed teachers with some CLIL experience. The third section, in particular, made use of a set of attitudinal and behavioral scale questions in order to obtain an accurate view of the range of intercultural techniques CLIL practitioners use in their classroom. Finally, section four attempted to explore the perceived benefits and challenges of CLIL by asking the respondents to choose from various response questions which emerged from the relevant literature review.

\section{The interviews}

For the purposes of this study, the researchers also carried out semi-structured interviews based on a preset interview guide. They were guided by the belief that this method of data collection would add to the breadth and depth of the conversational dialogues they meant to have with the interviewees, keeping at the same time the discussions within the desired plan of action. Most importantly, it was forming a relationship of trust that determined what got reported and allowed access to the complexities of the respondents' experiences.

\section{Lesson observations}

In conjunction with the questionnaire and the interviews, classroom-based observations were also used as a data collection instrument. Adopting the role of a non-participant observer, the researchers had the chance to see directly what a CLIL learning environment looks like. In general, lesson observations enabled them to witness phenomena in an unobtrusive way. Thereafter, field notes included both descriptive information taken during the course of the observation and reflective information, "selecting and portraying details that resonate with the study's purposes" (Glesne, 1998, p. 149). All in all, lesson observations afforded new vantage points from which insightful understandings were gained.

\section{Participants}

A total of sixty primary school EFL teachers, fifty-three women (88.3\%) and seven men (11.7\%) completed the questionnaire administered from January 3rd through February 6th 2019. Most of the respondents had a relative extensive teaching experience. Specifically, 38.3\% of the surveyed sample reported having 11-15 years of teaching experience, while a big percentage of the study population had a vast amount of teaching experience, (namely 20\% reported 21-25 years of teaching background, $18.3 \%$ indicated having 16-20 years of teaching experience, while $15 \%$ exceeded 26 years of work in the educational sector). In contrast, $5 \%$ had a teaching background of 6-10 years, while only two respondents (3.3\%) belonged to the $1-5$ years of educational practice group. As regards their current teaching situation, the majority of those who responded $(68.3 \%)$ worked in a state primary school, whereas $21.7 \%$ were employed in a primary private institution. Unfortunately, of the 12 model / experimental schools contacted, just a small number of teachers $(10 \%)$ returned the questionnaire. Moreover, from the study population six teachers consented to being interviewed, while one of the interviewees allowed us access to her class, for three consecutive teaching sessions. 


\section{Data analysis}

The findings concerning the participants' intercultural profile showed that the largest proportion of the respondents $(95 \%)$ had been abroad, mostly as a leisure pursuit $(80 \%)$, while a smaller percentage referred to having spent a period abroad to study $(26.7 \%)$ or even participate in teacher training courses $(21.7 \%)$. In addition, only $11.7 \%$ of the subjects who participated in the survey listed overseas visits as part of a collective institutional undertaking (Erasmus mobility programs and so forth). Unarguably, the gains that result from the exchange of expertise on pedagogical matters in teacher mobility projects far outweigh the benefits of travelling for pleasure, albeit invaluable for the individual teacher.

If we now turn to the languages spoken by the participants, while few respondents have indicated fluent command of other languages (e.g. French: 22.2\%, German: 11.1\%, Spanish: $6.3 \%$, Italian: $5 \%$ ), the overall number of languages spoken other than English, even on a basic conversational level, implied a significant degree of familiarity with cultural otherness. However, when asked whether they had received any form of training in intercultural education, the overwhelming majority of the surveyed teachers (70\%) stated that they had not received any intercultural coaching. A further processing of this finding indicated that $(78 \%)$ of the participating state school teachers lacked any training in intercultural education. In contrast, a lower percentage of private school (62\%) and model/experimental school teachers $(33 \%)$ reported that they had not received any intercultural instruction. Overall, the findings indicated that Greek EFL teachers in their vast majority lack a good depository of intercultural teaching ways.

\section{Perceived importance of ICC}

In general, the view that intercultural teaching plays an active role in preparing learners for future interactions in a globalized society, was shared by most teachers $(56.7 \%)$. In the same vein, the majority of EFL teachers (56.7\%) perceived culture teaching as important as language teaching and accordingly, considered intercultural knowledge objectives of paramount importance in the current curricular framework. However, the present study also shed light on the inherent contradictions between theory and practice since despite their positive disposition towards intercultural teaching, the majority of the participants $(60 \%)$ regarded it merely as an add-on element to their practice. In other words, even though ICC was highly valued as a crucial factor for the development of the learners' communicative competence across diverse cultural contexts, it was not prioritized in praxis. Moreover, the largest proportion of the participants affirmed that assessment should not be a part of intercultural teaching and learning, rendering intercultural competence performance an obscure business.

From another perspective, a significant finding showed that EFL primary teachers conceptualize intercultural teaching as a feasible goal even when dealing with students with a less advanced level of linguistic proficiency, implying an intercultural turn in early EFL primary education. Nonetheless, since most respondents embraced the depositing role of culture teaching, we can argue that the findings revealed a persistence of long-established teacher-directed ways, 
which inhibit active exploration and constructive engagement. At this point, we should stress that dominant cultures continue to receive emphasis from the EFL primary teachers participating in the survey.

Similarly, the findings pertaining to the goals of EFL that the participants valued the most provide evidence that teachers favor goals related to the acquisition of skills, both receptive and productive. It therefore seems that Greek EFL teachers have deep-rooted views about L2 goals referring to learning the language per se and assuming that linguistic competence results automatically through effective communication. In this vein, the majority of the surveyed population highly regarded instrumental goals such as preparing students for interactions with native speakers of English as well as with non-native ones (56.7\% and $46.7 \%$ respectively), manifesting a weakening of the near-native speaker ideal. On the other hand, the overwhelming majority $(68.3 \%)$ considered instilling motivation and interest in language learning of great significance, linking successful language learning to intrinsic motivational factors. Nevertheless, the goal of preparing students for the requirements of formal examinations, which obviously touches upon issues of accountability, was deemed secondary by the participants.

Admittedly, it seems paradoxical that in a context where communicative competence is highly valued, ICC is not prioritized. Alarmingly, even though, as already stated, the respondents ranked the goal of preparing their students for future interpersonal situations high, only $33.3 \%$ of them regarded the skill-related goal of equipping learners for possible misunderstandings when interacting with people from diverse cultural backgrounds as very important. On the other hand, the knowledge-based goals of promoting students' familiarity with the culture of Englishspeaking countries received a higher response rate $(46.7 \%$ considered it very important while $45 \%$ thought of it as important). In contrast, promoting the culture of diverse ethnic and social groups received a comparatively lower score (26.7\%: Very Important, 48.3\%: Important), implying a false construct of culture in this context. In addition, only $21.7 \%$ of the respondents regarded promoting increased understanding of the students' own culture as very important. Likewise, only $26.7 \%$ of them placed emphasis on providing opportunities for comparing and contrasting the students' own culture and foreign cultures.

While the skills of interpreting and relating received little attention, which evinces a negligence of critical cultural awareness, attitudinal skills scored high. In particular, teachers were positive toward instilling intercultural attitudes of empathy, tolerance and openness and agreed that it is important to advance the value of cultural pluralism. On a final note, it could be argued that the majority of the surveyed teachers showed a willingness to help their students decenter. However, they had a vague idea of all the ICC dimensions involved in how to best achieve this.

\section{The cultural dimension in praxis}

Findings concerning the participating teachers' (inter)cultural practices corroborate what has been presented so far to a great extent. In particular, the role of the teacher as information provider emerged again as a dominant practice since the vast majority of the respondents 
confirmed providing their students with information about the culture of English-speaking countries $(M=4.216)$ as well as about places, world festivals, events, food and drink $(M=4.000)$. Moreover, it came as no surprise that fewer teachers provided students with information about the culture of diverse ethnic groups $(\mathrm{M}=3.392)$ or touched upon topics such as human rights, prejudice, racism or minorities ( $\mathrm{M}=3.451)$, which largely deviate from the "tourist" definition of culture. Likewise, fewer teachers indicated organizing activities that raise the students' interest in lifestyles, values and behaviors $(\mathrm{M}=3.569)$.

In trying to find a viable method of raising cultural awareness, it seems that a non-negligible percentage of teachers exploited authentic materials such as films, videos or texts $(\mathrm{M}=3.363)$ and supplemented lessons with literary texts that explore various cultural issues and stereotypes (M3.325). However, if we consider that the respondents seemed to focus on dominant cultural representations, one may wonder whether these literary texts offer unbiased perspectives of culture.

A most striking result to emerge from the data is also the fact that few respondents had embraced cutting edge technological tools to promote opportunities for cross-border collaboration with other learners of English $(\mathrm{M}=2.765)$ or to familiarize their students with aspects of foreign cultures such as values, social etiquette and behaviors $(M=2.980)$. Similarly, just a small percentage of the participating teachers provided their students with opportunities to share their personal experiences with representatives of other cultures $(M=2.843)$. Additionally, few respondents acknowledged the need to design tasks through which students would explore any similarities or differences between their own and foreign perspectives on culture-conditioned matters $(\mathrm{M}=2.961)$.

On the other hand, although computer-mediated authentic intercultural experiences were not encouraged, simulated cultural encounters were favored. More specifically, evidence from the survey suggests that a considerable percentage of the teachers organized tasks around real life situations / simulations $(M=3.235)$, used interactive techniques such as dramatizations, role-plays and quizzes $(\mathrm{M}=3.706)$ or engaged their students in inquiry-based activities through which they would discover otherness $(\mathrm{M}=3.314)$. All the same, the less frequent occurrence of such studentcentered activities, bring to the fore a teacher-directed orientation, which in turn is consistent with our earlier findings. Last, other experiential activities such as organizing celebrations around foreign festivals attracted the least attention $(\mathrm{M}=2.549)$. Overall, it seems that teachers were generally positively predisposed toward employing intercultural practices, adopting, however, the transmission model of teaching. The results also offer powerful evidence that in doing so, Greek EFL teachers favor traditional cultural topics.

\section{CLIL as a method for developing intercultural sensitivity}

Before proceeding to the findings pertaining to the intercultural gains of CLIL, it was deemed necessary to investigate the degree to which EFL primary teachers were familiar with this approach. To this end, it was found that $48.3 \%$ of the respondents were well-versed in CLIL, while $36.7 \%$ indicated having only a vague idea. What is more, $15 \%$ of the study population 
admitted having no idea about CLIL. In an attempt to shed more light on this issue, a Cross tabulation was carried out exploring the identity of those who were familiar and those who were not. From its results we can deduce that the older the teaching population gets, the less they know about CLIL. Moreover, it can be assumed that teachers with more academic qualifications tend to be more knowledgeable about CLIL. Last, the findings revealed that Model / Experimental school teachers were better-informed, while state school teachers were the least knowledgeable. Nevertheless, when asked whether they wished to know more about CLIL, only 2 respondents out of the 10 who admitted having no idea declared they were not interested at all. It is also worth mentioning that the respondents who indicated being familiar with CLIL mostly attributed this to intrinsic reasons such as personal motivation or interest in professional development.

With regard to the analysis of the perceived strengths of the CLIL approach, the questionnaire results draw our attention to its potential toward building intercultural sensitivity, which constitutes the affective aspect of ICC in which intercultural effectiveness is grounded. On the whole, the findings were very encouraging. In particular, the vast majority of the respondents agreed that CLIL fosters an attitude of openness and curiosity toward other cultures $(M=4.353)$, which undoubtedly contributes to minimizing any denial. On the other hand, a big percentage of the surveyed teachers confirmed that CLIL deepens their students' awareness of "otherness" and self $(\mathrm{M}=3.961)$. CLIL therefore emerges as a major factor affecting understanding of cultural differences, which is a prerequisite of critical cultural awareness.

Apart from nurturing a positive disposition toward cultural difference $(M=4.137)$, the findings revealed that CLIL promotes a proactive intercultural perspective. To be specific, the respondents indicated that CLIL fosters a willingness to question familiar presuppositions $(M=3.804)$ and equips students with the necessary skills to identify possible areas of misunderstandings while interacting with others $(\mathrm{M}=3.863)$. In retrospect, it appears that CLIL does not only cultivate an empathic ability to understand otherness but also has behavioral implications, since it enables the students to adopt an ethno-relative stance and adapt their behavior to diverse intercultural settings. Unarguably, this is also reinforced by the big percentage of teachers who felt that CLIL prepares students for successful interactions with others $(\mathrm{M}=4.196)$.

\section{Perceived benefits and/or constraints of CLIL}

Alongside the intercultural gains delineated above, the results of the questionnaire imply that there are additional benefits which relate to the teaching and learning of EFL in general. In particular, CLIL is believed to maximize exposure to the target language $(M=4.569)$, thus positively affecting fluency in $\mathrm{L} 2(\mathrm{M}=4.353)$ as well as accuracy, albeit to a lesser extent (3.569). Possibly, there is a significant correlation of the particular findings with the fact that most participants reported that CLIL enhances students' confidence in language use $(M=4.392)$ and generally builds positive attitudes toward FL learning (4.471). Moreover, since CLIL develops subject-specific terminology alongside content knowledge $(\mathrm{M}=4.294)$, it is thought to 
have a subsequent beneficial impact on content achievement $(\mathrm{M}=4.078)$. Last but not least, it appears that CLIL supports the development of critical skills which are necessary for constructing knowledge and problem solving (M=4.216). All in all, it seems that CLIL offers increased opportunities to learn the language, which may be regarded as a stepping stone for intercultural competence given that language and culture are inextricably tied.

Still, the present research substantiates that there are considerable challenges to overcome. A significant result to emerge from the data is that the overwhelming majority of the respondents considered lack of CLIL-specific training opportunities as a barrier to CLIL implementation $(\mathrm{M}=4.471)$. Similarly, they strongly agreed that lack of administrative support constitutes a major hindrance encountered by educators $(M=4.137)$. In the same vein, most teachers $(\mathrm{M}=4.000)$ stated that there is no CLIL coordinator who would act as a kind of liaison between teachers, administrators and students.

Furthermore, the lack of training as well as the absence of official guidance may account for challenges such as lack of experience in cross-curricular teaching $(\mathrm{M}=3.941)$, lack of culturespecific knowledge (3.275) as well as low confidence (3.078). Without a doubt, there is a growing consensus that the Greek educational system has not provided the teachers of English with the knowledge and skills required to perform effectively in a CLIL classroom. For this exact reason, CLIL was perceived as time-consuming. A big number of respondents indicated that the courseware they used did not include cross-curricular sections $(\mathrm{M}=3.333)$ in addition to the fact that they lacked the time needed to supplement or adapt the material available $(\mathrm{M}=3.980)$. To this end, most respondents $(\mathrm{M}=4.118)$ also pointed to the lack of ready-made CLIL resources.

From another point of view, some teachers put to the fore constraints of a more contextualized nature. In particular, there were respondents who attributed their reticence to implement CLIL to a lack of communication channels between teachers of different subjects $(M=4.000)$. Furthermore, a considerable percentage of the participants surveyed $(\mathrm{M}=3.353)$ called attention to a strict separation of content and subject teaching in their institution. Last but not least, parental opposition received the lowest response rate $(\mathrm{M}=2.941)$. Accordingly, it can be argued that parents do not oppose progressive pedagogies such as CLIL.

However, evidence from the field notes suggests that the benefits outweigh any challenges. Classroom observation brought to light a learner-focused, supportive atmosphere, in which the students spoke with little hesitation (in the absence of negative feedback) and participated in authentic tasks that promoted peer-to-peer communication, negotiation of meaning and intellectual engagement. The students observed worked in online environments and made use of technological aids such as electronic dictionaries, Web-Quests, e-mails, interactive whiteboards.

Furthermore, it became clear that these learners were in charge of their own learning. They were highly-motivated individuals who relied on each other to seek answers to problems which did not simply generate factual knowledge. Instead, the students were involved in a wide range of mental processes which promoted higher order thinking. They understood perspectives, inferred meaning, compared, explained (using explicit criteria), and applied newly acquired information to create a product of their own. On the other hand, when it comes to the teacher, she 
was not there to disseminate knowledge but to help her learners construct it through active learning and enquiry. Obviously, she had expended a lot of time and effort to provide the scaffolding needed to ensure equal opportunities for success. This way, she went well beyond the conventional tools of the trade and made extensive use of carefully selected multi-modal authentic materials and allowed space for her students who explored global issues pertaining to citizenship education.

\section{Discussion}

With respect to the perceived importance of ICC, it seems that although there is explicit agreement among educators on the importance of intercultural objectives, the intercultural dimension lacks solidity in praxis. In essence, research findings demonstrated that the relationship between language and culture is far from symbiotic, with the linguistic element receiving more emphasis than the intercultural one. Accordingly, linguistic goals emerge as a priority, whereas culture is treated as an add-on extra. Evidently, Greek EFL teachers have yet to become competent intercultural mediators (namely, key figures who will prepare their learners for future interactions in a culturally diverse world). However, this failure to adopt an intercultural orientation in practice is linked to the insufficient training of teachers on intercultural matters. More specifically, limited training opportunities may be held accountable for the divide between intent and reality. Unarguably, poor training also accounts for low efficacy beliefs of EFL teachers who believe they are under-prepared for their intercultural mission. Ironically, by harboring feelings of inadequacy Greek EFL practitioners inadvertently sabotage themselves since poor expectations result in poor outcomes.

While EFL primary teachers in Greece lack the necessary disciplinary knowledge to promote ICC, they still remain motivated individuals, willing to go the extra mile in order to improve their expertise. In this light, persistence in traditional, teacher-fronted ways, which this research has unveiled, is not so much resistance to change as lack of know-how and skills to transform pedagogy and adopt innovative approaches. By and large, having explored the factors underlying the teachers' actual practices, it can be concluded that the ground is ripe for educational change. To this end, well-planned, sustained intercultural training might sow the seeds for transforming Greek EFL teachers into educators for the 21st century.

Regarding the place of the cultural component, results show that we have yet to witness a major shift in intercultural practices. Specifically, teachers seem to favor the cultural over the intercultural. Additionally, it becomes clear that the English language teacher adopts the role of the disseminator of knowledge while the learners remain totally uninvolved in the construction of it. In (inter)cultural terms, the prevalence of the knowledge-based paradigm treats culture as a body of static products that has to be taught explicitly rather than be integrated within language teaching. In this sense, the representation of culture in the Greek primary class remains problematic. For, it focuses on aesthetic products and activities, while it fails to embrace the anthropological dimension of culture as a highly complex entity, subject to ongoing change, and continuously redefined by social groups (Delanoy \& Volkmann, 2006). As the findings of the 
research indicate, Greek EFL primary teachers offer their students an unbalanced portrayal of culture revolving around inner circle countries. On the one hand, this attitude promotes dominant cultural discourses. Undoubtedly, apart from fostering an elitist conceptualization of culture, this fixation with the cultural norms of English speaking countries offers overly idealistic views of culture. On the other hand, this superficial approach perpetuates deeply entrenched stereotypes inherent in a tourist approach to culture. Last but not least, as evidenced in the study, English language teachers avoid touching upon taboo topics such as human rights, prejudice or racism, whereas they under-represent minorities or unprivileged social groups. Overall, this study has shed light on the discriminatory cultural practices prevalent in EFL primary education. Obviously, teachers themselves become carriers of deeply-embedded biases which undermine education for equity and justice.

A further processing of the findings denotes that while cultural knowledge receives attention, albeit in essentialized ways, developing ICC remains an unclear goal since not all dimensions of ICC are addressed in this context. In particular, as already mentioned, the teachers overly focus on the cognitive dimension of ICC, while intercultural skills and attitudes, despite being verbalized in the stated goals, are not articulated in practice. Evidence from the research suggests that EFL teachers in Greece do not engage their students in critical evaluation of cultural issues, fail to encourage them to reflect on their own experiences with representatives of other cultures and provide limited opportunities for comparing and contrasting cultures.

By comparing and contrasting, we invite students to re-examine their culturally-conditioned behaviors before attempting to approach the underlying values of others. Building ICC is not simply a matter of knowing about, but rather a matter of shedding our ethnocentric views of the world. EFL teachers, therefore, should first and foremost realize that intrapersonal as well as interpersonal understanding and interaction constitute the foundation stone of successful intercultural communication.

As far as the intercultural potential of CLIL is concerned, evidence suggests that CLIL breaks new ground in intercultural education. In contexts where the CLIL approach comes in, the development of ICC is treated as a transformative process rather than as knowledge to deposit. In particular, acknowledging that strengthening the attitudinal dimension of ICC constitutes a rudimentary step towards transforming our classrooms into "culturally sensitive place[s] to learn" (Porto, 2010, p. 47), the present study attempted to determine whether CLIL instruction helps learners broaden their worldview, contributing to anxiety and prejudice reduction. On the whole, even though psychological constructs are hard to measure, findings of the study indicate that CLIL instruction has the potential to cultivate a degree of intercultural sensitivity.

Taking a closer look, classroom observation has demonstrated that CLIL favors an opening to real world topics. In particular, the students explored global issues affecting Greece as well, and were encouraged to dispel stereotypical representations of racially-marked minority groups. Even though empathic respect for otherness has no immediate results in the primary classroom, it is exactly this kind of instruction who may nurture a willingness to speak out against expressions of prejudice and intolerance; a willingness to defend those who are disempowered and 
disadvantaged; and a willingness to take civic or political action for the greater good if this is required (Byram, Golubeva, Hui, \& Wagner, 2016, p. 8).

In many instances, it became clear that CLIL can be placed "within a discourse of change: changing educational practice, changing policy, or changing the world" (Smeyers \& Depaepe, 2016, p. 1). For, educators shake the habit of monopolizing classroom discourse redefining their roles, school policy focuses on planning instruction with an intercultural perspective and last but not least, the transformative CLIL pedagogy empowers educators and learners alike to become agents of change. On the other hand, it must be stressed that EFL educators cannot bear the sole responsibility for opening intercultural spaces. Succinctly, the involvement of the wider school community emerges as a necessary ingredient if we wish CLIL instruction to have a sustained impact. Without a doubt, this realization raises key issues for the public sector where CLIL instruction remains over-reliant on individual teachers' initiatives.

With respect to the benefits of CLIL instruction, findings point to various linguistic and cognitive gains. Evidently, CLIL enriches the agenda of traditional EFL instruction by introducing topics which are absent from the English primary classroom. Moreover, by adjusting cognitive demanding material, the learning experience is upgraded. In this sense, CLIL triggers learner engagement, which, by determining how much effort learners put in as well as their affective involvement, is a strong predictor of success. Learners themselves are trained in autonomy, for they are encouraged to seek answers to problems applying creativity and critical thinking. Most importantly, CLIL redefines relationships among students, who learn to cooperate rather than compete in order to achieve a common goal. Obviously, CLIL instruction draws on the principle of reciprocity, as worded by Chickering and Gamson: "Learning is enhanced when it is more like a team effort than a solo race. Good learning, like good work, is collaborative and social, not competitive and isolated" (1987, p. 3). Overall, CLIL instruction changes our ideas of what we can teach and how far we can go in primary education. Last but not least, since CLIL promotes the belief that subjects are linked together, its legacy rests with shaking the dominant work ethics at schools, since teachers of various subjects are encouraged to go beyond their areas of specialism sharing a joint vision.

Clearly, "CLIL is a typical case of an educational innovation which outpaces teacher education provision" (Mehisto, Marsh \& Frigols, 2008, p. 21, cited in Mattheoudakis et al., 2011, p. 220). Accordingly, in trying to determine the main challenges experienced by the participants in this survey, lack of CLIL-specific training opportunities emerged as a major area of concern. While teachers of model / experimental and private educational institutions appear to be better informed, EFL teachers in the public sector rely on their self-propelled exploratory initiatives. Evidently, inchoate, teacher-led initiatives are doomed to failure without sustained policy support. In other words, taking also into consideration the absence of clearly-defined assessment criteria, it can be argued that CLIL success is not self-evident. Further to this, sustainability and ongoing CLIL implementation and development are also threatened by the lack of continuity which pervades the Greek education system. It is a shared secret that EFL teachers often change 
schools and never reap the fruit of their hard work. Moreover, transition to secondary education does not ensure further continuation of the positive outcomes.

That being said, it becomes clear that local factors impinge on the success of CLIL in Greek primary education. In many ways, CLIL provision is becoming an elitist approach, inaccessible for the students of the public sector. Unarguably, this sad reality contradicts the egalitarian nature of CLIL.

\section{References}

Agar, M. H. (1994). Language shock: Understanding The Culture of Conversion. New York: William Morrow.

Bennett, J. M., Bennett, M. J., \& Allen, W. (2003). Developing intercultural competence in the language classroom. In D. L. Lange \& R. M. Paige (Eds.), Culture as the core: Perspectives on culture in second language learning (237-270). Greenwich, CT: Information Age Publishing.

Byram, M. (1989). Cultural studies in foreign language education. Philadelphia: Multilingual Matters.

Byram, M. (1997). Teaching and Assessing Intercultural Communicative Competence. Clevedon: Multilingual Matters.

Byram, M. (2008). From Foreign Language Education to Education for Intercultural Citizenship: Essays and Reflections. Clevedon: Multilingual Matters.

Byram, M. \& Fleming, M. (Eds.) (1998). Language Learning in Intercultural Perspective. Approaches through drama and ethnography. Cambridge: Cambridge University Press.

Byram, M., Gribkova, B. \& Starkey, H. (2002). Developing the Intercultural Dimension in Language Teaching: A Practical Introduction For Teachers. Council of Europe.

Byram, M., Golubeva, I., Hui, H. \& Wagner, M. (Eds.) (2016). From Principles to Practice in Education for Intercultural Citizenship (Vol. 30). Clevedon: Multilingual Matters.

Cakir, I. (2006). Developing Cultural Awareness In Foreign Language Teaching. Turkish Online Journal of Distance Education, Vol. 7, No. 3, 154-161.

Retrieved from http://tojde.anadolu.edu.tr/yonetim/icerik/makaleler/283-published.pdf

[accessed on 1 July 2018]

Chen, G. M. \& Starosta, W. J. (1996). Intercultural communication competence: A synthesis. In B. Burleson (Ed.), Communication Yearbook 19 (353-383). Thousand Oaks: Sage.

Chickering, A. W., \& Gamson, Z. F. (1987). Seven principles for good practice in undergraduate education. $A A H E$ Bulletin, Vol. 3, 3-7.

Council of Europe (2001). Common European Framework of Reference for Languages: Learning, teaching, assessment. Strasbourg: Cambridge University Press.

Retrieved from https://rm.coe.int/1680459f97[accessed on 5 October 2018]

Coyle, D. (2000). Meeting the Challenge: The 3Cs Curriculum. In S. Green, (Ed.), New Perspectives on Teaching and Learning Modern Languages: Modern Languages in Practice (158-181). Clevedon: Multilingual Matters.

Coyle, D. (2008). Content and Language Integrated Learning: Motivating Learners and Teachers. Retrieved from http://blocs.xtec.cat/clilpractiques1/files/2008/11/slrcoyle.pdf

[accessed on 28 September 2018]

Coyle, D. (2009). Promoting cultural diversity through intercultural understanding: A case study of CLIL professional development at in-service and pre-service levels. In M. L. Carrio-Pastor (Ed.). Linguistic Insights: Studies in Language and Communication, Number 92 (105-130), Bern: Peter Lang. 
Coyle, D., Holmes, B. \& King, L. (2009). Towards an integrated curriculum - CLIL National Statement and Guidelines. U.K: The Languages Company.

Coyle, D., Hood, P. \& Marsh, D. (2010). Content and Language Integrated Learning. Cambridge: Cambridge University Press.

Crozet, C. \& Liddicoat, A. J. (2000). Teaching Culture as an integrated part of language: Implications for the aims, approaches and pedagogies of language teaching. In A. J. Liddicoat \& C. Crozet (Eds.), Teaching Languages, Teaching Cultures (1-18). Applied Linguistics Association of Australia, Melbourne: Language Australia.

Dalton-Puffer, C. (2007). Discourse in Content and Language Integrated Learning (CLIL) Classrooms. John Benjamins Publishing Company.

Dalton-Puffer, C. (2008). Outcomes and processes in content and language integrated learning (CLIL): Current research from Europe. In W. Delanoy \& L. Volkmann (Eds.), Future perspectives for English language teaching (139-157). Heidelberg: Winter.

Dalton-Puffer, C., Nikula, T. \& Smit, U. (Eds.) (2010). Language Use and Language Learning in CLIL Classrooms. Amsterdam / Philadelphia: John Benjamins Publishing Company.

Delanoy, W. \& Volkmann, L. (2006). Cultural Studies in the EFL Classroom. Universitatsverlag C. Winter.

Diamantidaki, F. \& Carruthers, K. (2018). The Teaching and Learning of Chinese in Primary Schools in England: Developing a New Learning Approach to Support Intercultural Understanding. In R. Race (Ed.), Advancing Multicultural Dialogues in Education (71-85). Switzerland: Palgrave, Macmillan.

Eurodice, European Union Directorate-General for Education and Culture (2006). Content and Language Integrated Learning (CLIL) at School in Europe. Brussels: Eyrodice European Unit. Retrieved from

http://www.indire.it/lucabas/lkmw_file/eurydice/CLIL_EN.pdf [accessed on 6 October 2018]

Eyrodice (2012). Key data on education in Europe. Brussels: Education, Audiovisual and Culture Executive Agency.

European Commission (1995). White Paper on Education and Training: Teaching and Learning Towards the Learning Society. Brussels, COM (95) 590 final. Retrieved from https://publications.europa.eu/en/publicationdetail/-/publication/d0a8aa7a-5311-4eee-904c-98fa541108d8/language-en[accessed on 5 October 2018]

Fantini, A. E. (2009). Developing Intercultural Competencies: An Educational Imperative for the 21st Century. Studies in Language and Literature, Vol. 28, No. 2, p. 193-213.

Friedrich, P. (1989). Language, ideology and political economy. American Anthropologist, 91, 295-305.

Forbes, S. (1996). Values in Holistic Education. Retrieved from http://www.putnampit.com/holistic.html[accessed on 10 November 2018]

Gabillon, Z. \& Ailincai, R. (2013). CLIL: A Science Lesson with Breakthrough Level Young EFL Learners, Education, Vol. 3, No. 3, 168-177.

Glesne, C. (1998). Becoming Qualitative Researchers. Longman.

Griva, E., Chostelidou, D. \& Panteli, P. (2014). Insider views of CLIL in primary education: challenges and experiences of EFL teachers. International Journal for Innovation Education and Research, Vol. 2, No. 8, 31-54.

Griva, E. \& Deligianni, A. (2017a). CLIL Implementation in Foreign Language Contexts: Exploring Challenges and Perspectives. Research Papers in Language Teaching and Learning, Vol. 8, No. 1, 8-14.

Griva E. \& Deligianni, A. (2017b). CLIL - from theory to practice: challenges and perspectives. An Interview with Dr Marina Mattheoudakis. Research Papers in Language Teaching and Learning, Vol. 8, No. 1, 15-21.

Griva E. \& Kasvikis, K. (2014). CLIL in Primary Education: Possibilities and Challenges for Developing L2/FL Skills, History Understanding and Cultural Awareness. In N. Bakić-Mirić \& D. Erkinovich Gaipov (Eds.), Current trends and issues in education: an international dialogue. Cambridge Scholars Publishing. 
Griva, E. \& Zorbas, V. (2017). Multicultural and citizenship awareness through language: Cross thematic practices in language pedagogy. Hauppauge, New York: Nova Science Publishers.

Hillyard, S. (2011). First Steps in CLIL: Training the Teachers. Latin American Journal of Content \& Language Integrated Learning, Vol. 4, No, 2, 1-12.

Holliday, A., Hyde, M. \& Kullman, J. (2004). Intercultural communication: an Advanced Resource Book. London: Routledge.

Kachru, B. B. (1985). Standards, codification, and sociolinguistic realism: the English language in the outer circle. In R. Quirk \& H. G. Widdowson (Eds.), English in the World: Teaching and learning the language and literatures (11-30). Cambridge: Cambridge University Press.

Kamarianos, I., Katsillis, M., Zorbas, V. (eds.). (2017). Higher Education and Democracy: a work in progress [Special Issue]. Academia. Issue 9. (ISSN 2241-1402). http://academia.lis.upatras.gr/index.php/academia/index

Karakatsanis, D., Spinthourakis, JA, Zorbas, V. (eds). (2018). Identity in times of Crisis, Globalization and Diversity: Practice and Research Trends. (vols I \& II). London, UK: CiCea / CiCe Jean Monnet Network.

Koro, R. (2016). To what extent is a CLIL approach useful in teaching intercultural understanding in MFL? University of Reading. Retrieved from

http://centaur.reading.ac.uk/73485/1/20009322_Koro_thesis.pdf

[accessed on 26 June 2018]

Kramsch, C. (1995). The Cultural Component of Language Teaching, 1-11. Retrieved from

https://www.researchgate.net/publication/232850687 The Cultural_Component of Language Testing

[accessed on 2 July 2018].

Kramsch, C. (1998a). Language and Culture. Oxford: Oxford University Press.

Kramsch, C. (1998b). The priviledge of the intercultural speaker. In Byram, M. \& Fleming, M. (Eds.) Language Learning in Intercultural Perspective. Approaches through drama and ethnography (16-31). Cambridge: Cambridge University Press.

Liddicoat, A.J., Papademetre, L., Scarino, A., \& Kohler, M. (2003). Report on intercultural language learning. Canberra ACT: Commonwealth of Australia.

Liddicoat, A. J. \&Scarino, A. (2013). Intercultural Language Teaching and Learning. West Sussex: WileyBlackwell.

Lo Bianco, J. L. \& Crozet, C. (2003). Teaching Invisible Culture. Classroom practice and theory. Melbourne: Language Australia.

Manjarrés, N. B. (2009). Intercultural Competence: Another Challenge. Profile, No.11, 143-158.

Marsh, D. (2002). CLIL/EMILE - the European dimension: Actions, Trends and Foresight Potential.UniCOM: University of Jyväskylä, Finland.

Marsh D. \&Langé, G. (2000). Using Languages to Learn and Learning to Use Languages. TIE-CLIL: Jyväskylä and Milan.

Marsh, D., Pérez Cañado, M. L. \& Padilla, J. R. (Eds.) (2015). CLIL in Action. Voices from the Classroom. Cambridge Scholars Publishing.

Mattheoudakis M. \& Alexiou, T. (2017). Sketching the Profile of the CLIL Instructor in Greece. Research Papers in Language Teaching and Learning, Vol. 8, No. 1, 110-124.

Mattheoudakis, M., Alexiou, T. \&Laskaridou, C. (2011). To CLIL or not to CLIL? The Case of the 3rd Experimental Primary School in Evosmos. Retrieved from

http://www.enl.auth.gr/gala/pubs/files/7 Mattheoudakis\%20et\%20al.pdf

[accessed on 14 October 2018] 
Mathews, G. (2000). Global Culture / Individual Identity: Searching for home in the cultural supermarket. In A. Holliday, M. Hyde \& J. Kullman (Eds.), Intercultural communication: an Advanced Resource Book (71-73). London: Routledge.

McDougald, J. (2013). The CLIL Approach: A Gateway to Interculturality in the classroom. Retrieved from

https://www.academia.edu/4768500/The_CLIL_Approach_A_Gateway to interculturality in the classroom[acces sed on 27 June 2018]

Mehisto, P. \& Asser, H. (2007). Stakeholder Perspectives: CLIL Programme Management in Estonia. International Journal of Bilingual Education and Bilingualism, Vol. 10, No. 5, 683-701.

$\begin{array}{llllll}\text { Mehisto } & \text { P. } & \text { (2008). } & \text { Cxploring } & \text { Retrieved from }\end{array}$ http:/www.onestopenglish.com/clil/methodology/articles/article-exploring-clil/500470.article [accessed on 3 February 2019]

Mitchell, R., \& Myles, F. (2004). Second language learning theories. London: Arnold.

Morgan, C. \& Cain, A. (2000). Foreign Language and Culture: Learning from a dialogic Perspective.Clevedon: Multilingual Matters.

Oikonomou, K. (2013). Applying CLIL in Greek Schools. Notes from teaching in a provincial high-school.

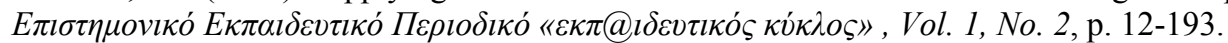

Papademetre, L., \& Scarino, A. (2006). Teaching and learning for intercultural communication: A multi-perspective conceptual and applied journey for teachers of world culture languages. Adelaide: UniSA.

Papadopoulos, I. \& Griva, E. (2014). «Learning in the Traces of Greek Culture»: A CLIL Project for Raising Cultural Awareness and Developing L2 skills. International Journal of Learning, Teaching and Educational Research, Vol. 8, No. 1, 76-92.

Papakyritsopoulou, E. \& Zorbas, V. (2018). Cultural Diversity and the Teaching of English: Teachers' and Immigrant Students' Attitudes and Views. New York: Nova Science Publishers.

Papalexatou, E. \& Zorbas, V. (in press- 2019). Bilingual students in the primary education context in Greece: A deterrent for the Greek educational landscape or a chance for improvement? In Skourtou, E., Kourtis-Kazoullis, V., Aravossitas, T. and Trifonas, P. (eds). Language Diversity in Greece: Local Challenges with International Implications. Switzerland: Springer International Publishing.

Papalexatou, E. \& Zorbas, V. (in press -2019). Probing into the cultural identity of Roma students: A case study in the Greek EFL context. In Krzywosz-Rynkiewicz, B. and Stara, J. (eds.), Europe at a Crossroads: Rights, Values and Identity. Huddersfield, UK/Prague, CZ: CiCea and Charles University.

Papalexatou, E. \& Zorbas, V. (2017). Fusing an L1 identity into an L3 context: Implications for foreign language pedagogy in Greece. In Karakatsanis, Spinthourakis, Zorbas (eds.), Identity in times of Crisis, Globalization and Diversity: Practice and Research Trends. London, UK:CiCea / CiCe Jean Monnet Network.

Papalexatou, E. \& Zorbas, V. (2015). Towards gradual first language (L1) attrition?: Cross-linguistic choices of two bilingual students learning English (L3). In Leslie Bash \& George Nikolaou (Eds.) Cultural Diversity, Equity and Inclusion:Intercultural Education in 21st century and beyond. International Association for Intercultural Education.

Porto, M.(2010). Culturally Responsive L2 Education: an Awareness-raising Proposal. ELT Journal, Vol. 64, No. 1, 45-53.

Quist, G. (2013). Reading With My Eyes Open: Embracing the critical and the personal in language pedagogy. London: Ubiquity Press.

Race, R. (2011). Multiculturalism and Education. New York: Continuum

Race, R. (2018). Advancing Multicultural Dialogues in Education. Switzerland: Palgrave, Macmillan. 
Rashid, N. \&Tikly, L. (2010). Inclusion and Diversity in Education: Guidelines for Inclusion and Diversity in Schools. Retrieved from https://www.britishcouncil.es/sites/default/files/british-council-guidelines-for-inclusionand-diversity-in-schools.pdf[accessed on 4 July, 2018]

Reimann, A. (2010). Raising Cultural Awareness as part of EFL Teaching in Japan. Retrieved from

https://www.researchonline.mq.edu.au/vital/access/services/Download/mq:17872/SOURCE3?view=true[accessed on 30 June 2018]

Risager, K. (2005). Languaculture as a key concept in language and culture teaching. In B. Preisler, A. Fabricius, H. Haberland, S. Kjaerbeck\& K. Risager (Eds.), The Consequences of Mobility: Linguistic and Sociocultural Contact Zones (185-196). Roskilde: Roskilde University.

Risager, K. (2007). Language and Culture Pedagogy. From a National to a Transnational Paradigm.Clevedon: Multilingual Matters.

Ruiz de Zarobe, Y. R. \&Catalán, R. M. J. (2009). Content and Language Integrated Learning: Evidence from Research in Europe.Clevedon: Multilingual Matters.

Saniei, A. (2012). Developing Cultural Awareness in Language Instructional Materials. International Conference on Language, Medias and Culture, Vol. 33, 10-15.

Scarino, A. \& Liddicoat, A. J. (2009). Teaching and Learning Languages: A Guide, 1-104. Retrieved from

https://www.researchgate.net/publication/242638731_Teaching_and_Learning_Languages_A_guide[accessed on 16 July 2018]

Sifakis, N. C. \& Sougari, A. M. (2003). Facing the Globalisation Challenge in the Realm of English Language Teaching. Language and Education, Vol. 17, No. 1, 59-71.

Smeyers, P. \& Depaepe, M. (Eds.)(2016). Educational Research: Discourses of Change and Changes of Discourse. Switzerland: Springer.

Smit, U. \& Dalton-Puffer, C. (Eds.) (2007). Current Research on CLIL 2, View[z] Vienna English Working Papers, Vol. 16, No. 3, 1-80. Retrieved from

https://www.unifg.it/sites/default/files/allegatiparagrafo/21-01-2014/views_current_research_on_clil_2.pdf [accessed on 5 July 2018]

Sudhoff, J. (2010). CLIL and Intercultural Communicative Competence: Foundations and Approaches towards a Fusion. International CLIL Research Journal, Vol. 1, No. 3, 30-37.

Takeuchi, A. (2015). Developing a Scale of Children's Intercultural Competence: Issues and Challenges, 45-58. Retrieved from

http://www.kyoai.ac.jp/college/ronshuu/no-15/2015-takeuchi.pdf[accessed on 25 July 2018]

Thanh, N. C. \& Thanh, T. T, L. (2015). The Interconnection Between Interpretivist Paradigm and Qualitative Methods in Education, American Journal of Educational Science, Vol. 1, No. 2, 24-27.

Tran, T. Q. \& Seepho, S. (2016). Intercultural Language Education: EFL Learners' perceptions toward Intercultural Language Communicative Teaching. Philippine ESL Journal, Vol.16, 46-64.

Young, T. J. \& Sachder, I (2011). Intercultural communicative competence: exploring English language teachers' beliefs and practices, Language Awareness, Vol. 20, No. 2, 81-98.

Zorbas, V.\& Papalexatou, E. (2016). Newcomers in Greek state schools: From classroom practice to policy making. Multilingual Academic Journal of Education and Social Sciences. Vol. 4, Issue 1, pp. 40-50. 